\section{PROFESIONALNI STRES KOD \\ SOCIJALNIH RADNIKA: IZVORI STRESA I SAGORIJEVANJE NA POSLU}

\section{SAŽETAK}

Profesionalni stres je pojava kojoj su nerijetko izloženi stručnjaci pomagačkih profesija, u koje se ubrajaju i socijalni radnici. Neusklađenost između zahtjeva vezanih uz posao i okoline, odnosno nemogućnosti da se tim zahtjevima udovolji dovode do profesionalnog stresa. Jedan od njegovih krajnjih negativnih ishoda je sagorijevanje na poslu, koje se najšire može shvatiti kao proces koji dovodi do potpune profesionalne iscrpljenosti $i$ u konačnici može rezultirati apatijom. Cilj ovog rada je dati uvid u istraživanja o izvorima stresa i sagorijevanju na poslu kod socijalnih radnika, s posebnim osvrtom na nalaze relativno rijetkih domaćih istraživanja, te pokušati objediniti najčešće nalaze o izvorima stresa i sagorijevanju na poslu kod socijalnih radnika.

' Doc.dr.sc. Olja Družić Ljubotina, socijalna radnica, e-mail: olja_druzic@yahoo.com

2 Dr.sc. Ljiljana Friščić, socijalna radnica, e-mail: Ijiljana.friscic@zg.htnet.hr
Pregledni članak

Primljeno: listopad, 2013.

Prihvaćeno: siječanj, 2014.

UDK $364.62: 331.442$

DOI 10.3935/ljsr.v21i1.10

Olja Družić

Ljubotina'

Studijski centar socijalnog rada

Pravni fakultet u Zagrebu

\section{Ljiljana Friščić ${ }^{2}$}

Ministarstvo socijalne politike i

mladih Republike Hrvatske

Ključne riječi:

profesionalni stres, izvori stresa, sagorijevanje na poslu, socijalni rad. 


\section{UVOD}

Danas područje socijalnog rada ne obuhvaća samo područje socijalne skrbi i rješavanje socijalnih problema, već ono u širem smislu podrazumijeva socijalne intervencije koje zahtijeva socijalna politika i socijalni razvoj. Zbog navedenog, socijalni radnici imaju vrlo važnu ulogu u prevenciji i rješavanju pojedinačnih i grupnih socijalnih problema. Od stjecanja neovisnosti u Republici Hrvatskoj potreba za socijalnim radom osjetno je povećana, i to iz dva osnovna razloga. $S$ jedne strane, zbog ratnih stradanja većina ljudi dospjela je u tešku životnu situaciju u kojoj im je bila potrebna pomoć. $S$ druge strane, prelazak iz socijalističkog sustava na tržišno gospodarstvo i pluralističko društvo uzrokovalo je pojačanu socijalnu diferencijaciju, pa su se s tim u vezi pojavili mnogi socijalni problemi koje je trebalo sustavno i stručno rješavati (Puljiz, 1997.).

$\mathrm{U}$ tom prijelaznom razdoblju velik dio aktivnosti preuzeli su socijalni radnici, prije svega u centrima za socijalnu skrb, koji su uz svoje redovne i složene poslove (nezaposlenost, siromaštvo, narušeni odnosi u obitelji, razvodi brakova, bolest, invaliditet, zlostavljanje i zanemarivanje djece, psihičke teškoće, poremećaji ponašanja mladih i dr.), dobivali i dodatne zahtjevne obveze kao što su: rad s prognanicima i izbjeglicama, poslovi tijekom tranzicije, kompletni postupci prilikom razvoda braka, osmišljavanje nedostatnih smještajnih kapaciteta, prebačaj nekih prava i oblika iz drugih sustava i dr.

Iz opisa poslova socijalnog radnika, vidljivo je da naglašena socijalna i humana dimenzija pristupanja svakom slučaju u socijalnoj skrbi nalaže visoko specijalizirane intervencije u najintimnija i najsloženija područja života pojedinaca i obitelji, a što se može negativno odraziti u osobnom i profesionalnom funkcioniranju socijalnih radnika (Kahn, 1993.; Zapf, 2002.). Centri za socijalnu skrb, u kojima je zaposlen najveći dio socijalnih radnika, danas izvršavaju oko 140 različitih poslova koji su u njihovoj nadležnosti i slove kao jedan od složenijih sustava u državi. lako s manjkom zaposlenih, bez dovoljno potrebnih edukacija i stručnih usavršavanja, čestim promjenama zakonskih regulativa, podložnosti medijskim prozivanjima, uz preveliku administraciju, socijalni radnici nastoje ublažavati složene i teške izazove socijalnog djelovanja. Uz obnašanje profesionalne uloge i zahtjeve koji se neprestano povećavaju unutar sustava socijalne skrbi, socijalni radnici suočeni su i s drugim, ne manje značajnim poteškoćama koje se odnose na obilježja radnog okruženja kao što su: ograničeni radni uvjeti, loša organizacija rada, loši fizički uvjeti, nesigurnost na radnom mjestu i dr. (Friščić, 2006.; Moštak Skupnjak, 2012.). Socijalni radnici u svom poslu često nailaze na svakodnevne neugodne situacije s obzirom da rade s osobama koje se nalaze u nekoj životnoj nevolji, koje su zbog toga često frustrirane, pa u ogorčenju mogu ponekad postati i nasilne. Opasnost

\section{6 članci}


od agresije i fizičkog napada (Friščić, 2006.) prisutna je osobito u radu s osobama s poteškoćama psihičkog zdravlja, s ovisnicima te s osobama koje u stresnim i kriznim situacijama mogu reagirati na nepredvidiv ili agresivan način, što socijalnim radnicima predstavlja dodatni izvor stresa. Ipak, zadovoljstvo u ovom zanimanju donose kvalitetno riješeni slučajevi zbrinute ili posvojene djece, resocijaliziranih osoba, zbrinutih starijih ljudi i drugih koji osjećaju i iskazuju zadovoljstvo i povjerenje u svog socijalnog radnika. Drugi izvor zadovoljstva jest zanimljiv timski rad sa suradnicima drugih zanimanja što često pruža i omogućuje stjecanje novih znanja i interdisciplinarnih spoznaja te može pridonositi zadovoljstvu u radu.

Sustav socijalne skrbi u Hrvatskoj je u posljednjih nekoliko godina u procesu reformiranja i usklađivanja sa standardima europskog socijalnog modela. Reforma koja je bila u provedbi prije nekoliko godina, pored ostalog, podrazumijevala je i modernizaciju sustava, njegovu postupnu decentralizaciju i uključivanje čimbenika civilnog društva u rješavanje socijalnih problema (Ministarstvo zdravstva i socijalne skrbi, 2010.). Ona se uglavnom odnosila na novi model rada centara za socijalnu skrb, koji nije bio pripremljen niti podržan u kadrovskom, organizacijskom i edukacijskom aspektu. Sve je to zahtijevalo nova prilagođavanja i samosnalaženja socijalnih radnika u organizacijskim i drugim pogledima (Ajduković i Urbanc, 2010.). Reforma je rezultirala novim Zakonom o socijalnoj skrbi koji je donesen 2011. godine (NN, 57/11), nakon čega su vrlo brzo uslijedile izmjene i dopune istog zakona (NN, 33/12), a s početkom 2014. godine je na snazi ponovno novi Zakon o socijalnoj skrbi (NN, 157/13), koji traži opet novu prilagodbu u radu stručnjaka unutar sustava socijalne skrbi. Ovako česte promjene mogu imati utjecaja na razinu stresa i zadovoljstva poslom i kod iskusnih socijalnih radnika (Thompson i sur., 1996.).

Za funkcioniranje socijalne države bitan je kvalitetan sustav socijalne skrbi koji odražava i razvija socijalnu dimenziju, štiti ranjive skupine i pojedince te djeluje na njihovo integriranje u društvo i u svijet rada. Unutar tog sustava jednu od vodećih uloga imaju socijalni radnici čije je uspješno djelovanje ključno za kvalitetno funkcioniranje sustava te je stoga važno upoznati izvore njihove snage i njihove ranjivosti. Prema Škrinjar (1996.), pomagači koji se odlučuju za takva zanimanja, često su entuzijasti, perfekcionisti i osobe koje idealiziraju svoje zanimanje i imaju visoka očekivanja te su česti kandidati za sagorijevanje.

Slijedom navedenog, može se reći da su socijalni radnici u svom svakodnevnom radu, kao i postavljanju i ostvarivanju dugoročnih profesionalnih ciljeva, izloženi različitim i složenim zahtjevima posla, koji mogu postati izvori njihovog stresa i utjecati na radno i životno zadovoljstvo. Stoga ćemo se u ovom radu posvetiti saznanjima u kontekstu profesije socijalnog rada, koja se odnose na izvore stresa i sagorijevanje na poslu. 


\section{PROFESIONALNI STRES}

Stanje stresa na poslu može se definirati kao niz, za pojedinca, štetnih, fizioloških, psiholoških i bihevioralnih reakcija na situacije u kojima zahtjevi posla nisu u skladu s njegovim sposobnostima, mogućnostima i potrebama (Sauter i Murphy, 1998.).

Naglasak novijih konceptualizacija je na interakciji osoba-okolina. Prema Ajduković i Ajduković (1996.), profesionalni stres označava nesuglasje između zahtjeva radnog mjesta i okoline spram naših mogućnosti, želja i očekivanja da tim zahtjevima udovoljimo. U Europskoj uniji, stres na radnom mjestu (eng. work-related stress, WRS), odmah nakon bolova u kralježnici, drugi je najčešći problem povezan s poslom koji pogađa $28 \%$ radnika u EU-u. Stres na radnom mjestu uzrok je više od četvrtine odsutnosti s posla zbog zdravstvenih tegoba povezanih s radom koje traju dva tjedna ili više (https://osha.europa.eu/en/publications/factsheets/22).

Nastojanjem da se rasvijetli fenomen psihološkog stresa u radnoj okolini razvijen je čitav niz modela koji se razlikuju po svojoj složenosti. Detaljnijom analizom mogu se u pravilu klasificirati u dvije skupine (Šverko, 1984.). Jednu čine uži modeli koji stres definiraju kao rezultat neodgovarajućih zahtjeva radne okoline koji su u neskladu s mogućnostima zaposlenih. $\mathrm{U}$ drugu kategoriju spadaju modeli koji koriste širi pristup te promatraju stres u radu kao izraz opće neravnoteže između karakteristika radne situacije i individualnih osobina radnika.

Intencija ovog rada nije dati prikaz različitih modela koji se odnose na profesionalni stres, no, potrebno je spomenuti jedan od najviše prihvaćenih - transakcijski model stresa. Ključni predstavnici ovog modela su Lazarus i njegovi suradnici, a ubraja se u suvremene transakcijske modele stresa, koji podrazumijevaju uzajamni odnos između pojedinaca i njegove okoline, odnosno onoga što se objektivno događa (Arambašić, 2003.). U okviru ovog modela stres se definira kao sklop emocionalnih, tjelesnih i bihevioralnih reakcija do kojih dolazi kada osoba procijeni neki događaj uznemirujućim, odnosno kao sklop psihičkih i tjelesnih reakcija na stresor koji pred osobu postavlja zahtjeve kojima ne može udovoljiti. Pritom je stresor ili izvor stresa vanjski događaj ili niz događaja koje osoba procjenujuje ugrožavajućima, a stres unutrašnje stanje ili doživljaj (Lazarus i Folkman, 1984.). Među komponentama stresa, transakcijski model stresa posebno ističe značaj kognitivnih procesa i individualnih razlika u procjeni događaja u vanjskoj sredini kao i međuovisnost čimbenika okoline i osobe koja doživljava stres, te promjenjivost spomenutih čimbenika pod utjecajem tekuće transakcije. Sa stanovišta koje zastupa Lazarus, ono što je stresno za jednu osobu u određenom trenutku ne mora biti stresno za drugu osobu ili za istu osobu u nekom drugom trenutku.

\section{8 članci}


Prema Cooper i Marshall (1976.), model stresa u radu čini pet izvora stresa koji dovode do negativnog stresnog ishoda. To su: 1) unutrašnji čimbenici organizacije, uključujući neadekvatne fizičke uvjete rada, radno preopterećenje ili vremenski pritisak; 2) uloga u organizaciji, uključujući ulogu dvosmislenosti ili sukob uloga; 3) razvoj karijere, uključujući nedostatak sigurnosti na radnom mjestu; 4) odnosi na radnom mjestu, uključujući loše odnose sa svojim šefom ili kolegom, neke ekstremne komponente (nasilje na radnom mjestu) te 5) organizacijska struktura i klima, uključujući malu mogućnost sudjelovanja u donošenju odluka te politiku radne organizacije.

Za razliku od prethodno navednih autora koji izvore (profesionalnog) stresa, jednako kao i Lazarus, tretiraju kao vanjske čimbenike, odnosno događaje koje osoba procjenujuje ugrožavajućima, Ajduković (1996.) pod stresorima navodi i komponente koje se odnose na specifičnosti pojedinca. Ovaj autor tako izvore stresa dijeli na vanjske i unutarnje. Pod vanjskim stresorima ili stresorima koji proizlaze iz osobina radne okoline, organizacije rada uloga i načina komuniciranja u organizaciji autor navodi: vremenski pritisak rokova; odgovornost bez mogućnosti utjecaja i moći; nejasno definirane uloge; premalo suradnika u timu u odnosu na zadatke i očekivanja; nejasnu podjelu odgovornosti i preklapanje nadležnosti; nejasno definirana pravila napredovanja, nagrađivanja i korištenja godišnjeg odmora; postojanje privilegija; nepostojanje sustava za profesionalno osposobljavanje u skladu s promjenjivim potrebama organizacije; pomanjkanje povratnih informacija; emocionalno iscrpljivanje; opasnost od fizičkog napada i tuđe agresije; lošu psihosocijalna klimu organizacije i dr. Pod stresorima koji ovise o samoj osobi ili (unutrašnjim izvorima) isti autor podrazumijeva osobe koje: imaju nerealna očekivanja od posla i ne uspijevaju se prilagoditi realitetu; imaju veliku potrebu za kontrolom situacije i perfekcionizmom; identificiraju se s poslom tako da im on postane jedino područje potvrđivanja; neučinkovito koriste radno vrijeme; nemaju listu radnih prioriteta tako da im je sve podjednako važno; osjećaju profesionalnu nekompetentnost i dr.

Kao što je iz prethodnih podjela vidljivo, stresori mogu proizlaziti iz osobina radne okoline, organizacije rada i načina komuniciranja u organizaciji, osobina pojedinaca, kao i mnogih drugih svakodnevnih čimbenika koje je teško uvijek kvalificirati u određene kategorije jer su previše ovisni o čitavom sklopu odnosa u ukupnoj socijalnoj situaciji u kojoj se događaju.

Cooper i suradnici (Cooper, Sloan i Williams, 1988.; O'Driscoll i Cooper, 2002.), primjenjujući transakcijski model stresa na profesionalni stres, usmjerili su se na tri ključna elementa: izvore profesionalnog stresa, posljedice po pojedinca i organizaciju te razlike u ličnosti i ponašanju. U ovom radu posebno ćemo se posvetiti prvim dvama elementima, a to su izvori profesionalnog stresa i posljedice po pojedinca. Kao posljedicu stresa posebno ćemo analizirati sagorijevanje na poslu. Naravno, sve će to biti razmatrano u kontekstu profesionalnog stresa kod socijalnih radnika. 


\section{Izvori stresa kod socijalnih radnika}

Svakodnevni i složeni profesionalni zahtjevi u radu s osobama kojima je potrebna pomoć i podrška zahtijevaju od socijalnog radnika velik angažman i emocionalnu predanost, zbog čega ovi stručnjaci bivaju izloženi stresu koji može imati različite ishode.

Istraživanja profesionalnog stresa među socijalnim radnicima u svijetu upućuju da je fenomen stresa konzistentno prisutan (Jones, 2001.), da je zanimanje socijalnog radnika jedno od najstresnijih zanimanja (Travers i Cooper, 1993.; Kahn, 1993.) te da je stres na poslu u ovoj profesiji u stalnom porastu (Coffey, Dugdill i Tattersall, 2004.). Istraživanjem opće procjene stresnosti posla u kojem je sudjelovalo 147 socijalnih radnika iz Centra za socijalnu skrb Zagreb, pokazalo se da svi procjenjuju stresnim svoj posao, dok ga njih 33\% smatra izuzetno stresnim (Friščić, 2006.).

Dosadašnja istraživanja profesionalnog stresa kod socijalnih radnika rezultirala su ukazivanjem na različite izvore stresa u radu (Ajduković, 1996.a.; Friščić, 2006.; Moštak Skupnjak, 2012. i drugi). Nacionalna asocijacija socijalnih radnika Amerike (NASW, 2010.) na svojoj mrežnoj stranici (http://workforce.socialworkers.org/ whatsnew/stress.pdf) objavila je rezultate istraživanja, provedenog online metodom na uzorku od 3653 svoja člana pod nazivom: Stres na poslu: kako se socijalni radnici nose s tim? Istraživanje je pokazalo da socijalni radnici u svakodnevnom radu, pružajući različite usluge, mogu doživjeti visoke razine stresa. Velik broj ispitanika (31\%) ocijenio je da je nedostatak vremena u obavljanju posla glavni izvor stresa, dok je $16 \%$ ispitanika za izvor stresa identificiralo teške i zahtjevne klijente. Od ostalih izvora stresa navode: produženje radnog vremena, nemogućnost balansiranja između privatnog i poslovnog života, minimalnu podršku kolega i supervizora, male mogućnosti napredovanja i promocije i sl. Istraživanje dalje pokazuje da najveći stres osjećaju socijalni radnici koji rade s osobama koje imaju probleme u psihičkom i mentalnom funkcioniranju, a što se pokazalo i u istraživanju Friščić (2006.) u Hrvatskoj. Također, visok stres iskazuju i socijalni radnici zaposleni u zdravstvu i zaštiti obitelji i djece, što je u skladu s drugim istraživanjima (Anderson, 2000.).

S obzirom na složenost zadataka, odnosno poslove kojima se bave socijalni radnici, nekoliko studija pokazalo je da određeni zahtjevi u skrbi za djecu mogu kod socijalnih radnika u socijalnim službama dovesti do toga da dožive više stresa, manje zadovoljstvo poslom, ograničenu potporu i više poteškoća u suočavanju sa stresom, ali se također pokazalo i da socijalni radnici koji rade sa starijim osobama imaju višu razinu stresa od socijalnih radnika koji rade s djecom (Bennett i Evans, 1993.; Coffey, Dugdill i Tattersall, 2004.; Collins, 2008.).

\section{0 članci}


Od ostalih izvora stresa koji pridonose nepovoljnim psihičkim i fizičkim posljedicama kod socijalnih radnika su: efekti radnog preopterećenja na osobni život, nedostatak kontrole nad radom i donošenjem odluka, nedostatak socijalne podrške, loše upravljanje i nejasna radna uloga (Michie i Williams, 2003.).

Jeleč Kaker (2009.), istražujući izvore stresa kod socijalnih radnika zaposlenih u zdravstvu, dolazi do pet faktora tzv. profesionalnog opterećenja. To su: radna opterećenost zbog konflikta stručnog i administrativnog rada i nejasnih profesionalnih uloga, napeti odnosi kao profesionalni pritisak, nedovoljna stručnost kao izvor profesionalne opterećenosti, profesionalna nesigurnost te odgovornost posla.

Kovačić (2003.) navodi neke specifične izvore profesionalnog stresa kod socijalnih radnika zaposlenih u sustavu socijalne skrbi. To su: prevelik broj korisnika, sve složeniji slučajevi koji zahtijevaju više vremena ili stručnog znanja, neprilagođenost sustava i zakona potrebama korisnika, nedovoljni raspon psihosocijalnih intervencija koje im stoje na raspolaganju, nedovoljne mogućnosti za materijalnom pomoći, nnedovoljna podrška i razumijevanje neposredno pretpostavljenih, neadekvatni uvjeti rada, osjećaj profesionalne usamljenosti, nedostatak suradnje s drugim institucijama, loši odnosi u stručnom timu te česta izloženost stručnjaka kritikama javnosti.

U istraživanju provedenom u Centru za socijalnu skrb Zagreb Friščić (2006.) navodi sljedeće izvore stresa u radu socijalnih radnika: osjećaj izloženosti i nesigurnosti na radnom mjestu, nesigurnost u vlastitu kompetenciju, ograničenje radnog mjesta u pogledu napredovanja, izvori vezani uz organizacija rada, fizički uvjete rada, ograničenje suradnje između institucija te tzv. nespecifični razlozi (više zaposlenika ženskog spola i veća udaljenost mjesta rada od mjesta stanovanja). Najučestaliji stresogeni čimbenik bio je »izloženost verbalnoj agresiji klijenta«.

S obzirom na specifičnosti profesionalne uloge socijalnih radnika, istraživanje Moštak Skupnjak (2012.), provedeno u Gradu Zagrebu i Zagrebačkoj županiji, pokazuje da postoji značajna razlika u procjeni izvora stresa, odnosno nepovoljnih okolnosti u profesionalnom radu, između socijalnih radnika zaposlenih u centrima za socijalnu skrb i socijalnih radnika zaposlenih u drugim ustanovama socijalne skrbi (dječji domovi, ustanove za djecu s teškoćama u razvoju, ustanove za djecu s poremećajima u ponašanju, domovi za stare i nemoćne osobe te zavodi za socijalno-zdravstvenu zaštitu). Pritom socijalni radnici zaposleni u centrima za socijalnu skrb procjenjuju značajno nepovoljnije okolnosti u profesionalnom radu u odnosu na djelatnike drugih ustanova socijalne skrbi jer je istraživanjem utvrđeno da socijalni radnici zaposleni u CZSS-ima u odnosu na ostale sudionike, značajno više kao izvore stresa navode: prevelik broj korisnika, složenije slučajeve koji zahtijevaju više vremena, nedovoljni raspon psihosocijalnih intervencija, neadekvatne uvjete rada te osjećaj profesionalne usamljenosti. 
Analizirajući navedena istraživanja, vidljivo je da su socijalni radnici izloženi nekim općim izvorima profesionalnog stresa, ali i izvorima koji su specifični za područje rada. Najpodložniji su tzv. vanjskim izvorima stresa, koji proizlaze iz osobina radne okoline, organizacije rada, uloga i načina komuniciranja u organizaciji (Ajduković, 1996.). Tako kao najčešće vanjske izvore profesionalnog stresa socijalni radnici izdvajaju radnu opterećenost (prevelik broj korisnika), kao i nejasnoću profesionalne uloge. Jedan od konzistentno navođenih izvora stresa je i nedostatak vremena u kvalitetnom obavljanju svoje uloge, a koji se logično nadovezuje na radnu opterećenost. Nadalje, kako u stranim, tako i u domaćim istraživanja pojavljuje se kao izvor stresa mala mogućnost napredovanja na radnom mjestu. Tu su prisutni i izvori stresa koji se odnose na specifičnosti pojedinih korisnika (koji imaju probleme u psihičkom i mentalnom funkcioniranju, djeca u skrbi), te općenito rad s teškim i zahtjevnim korisnicima, odnosno pojavu sve složenijih slučajeva koji zahtijevaju više vremena. Tu se javlja i osjećaj izloženosti i nesigurnosti na radnom mjestu, kao i problem balansiranja između profesionalnog i privatnog života, opet zbog velike opterećenosti poslom, kao i nedostatak socijalne podrške (od nadređenih i kolega).

Ovo su neki od najčešćih izvora stresa kod socijalnih radnika, pri čemu je važno uzeti u obzir specifične kulturološke uvjete pojedinih zemalja i sustava. Količina stresa koju osoba doživljava na poslu vjerojatno će biti rezultat interakcije više faktora, kao što su vrsta posla, jačina stresora, potpora koju prima na poslu i u privatnom životu te mehanizmi koje koristi u suočavanju sa stresom. Naime, kao što je ranije spomenuto, prema općeprihvaćenom transakcijskom modelu stresa, hoće li doći do nepovoljnih posljedica, kao što je, primjerice, sagorijevanje na poslu, posreduju načini suočavanja sa stresom, odnosno procjena važnosti i mogućnosti utjecaja na izvor stresa. No, s obzirom na složenost ovih koncepata, koji nadilaze okvire ovog rada, ovdje neće biti riječi o suočavanju sa stresom, već ćemo se u nastavku osvrnuti na posljedice stresa, specifičnije, na sagorijevanje na poslu kod socijalnih radnika.

\section{Sindrom sagorijevanja na poslu kao posljedica profesionalnog stresa}

Stresni uvjeti na poslu mogu dovesti do brojnih negativnih posljedica kod pojedinaca, kao što su iscrpljenost, profesionalno sagorijevanje, opadanje u radnom učinku te do drugih zdravstvenih problema i pojavnosti, kao što su pretjerano konzumiranje alkohola, kofeina, pušenja, preskakanje obroka i dr. (Cooper, Dewe i O’Driscoll, 2001.). Jedna od češćih i najistraživanijih negativnih posljedica profesionalnog stresa u pomagačkim profesijama jest sagorijevanje na poslu. Termin

\section{2 članci}


"sagorijevanja na poslu« (eng. burnout) prvi je uveo psiholog Herbert Freudenberger (1974.) koji sagorijevanje definira kao stanje preopterećenosti ili frustracije izazvane prevelikom privrženosti i odanosti nekom cilju. Nadalje, isti autor opisuje sagorijevanje kao negativno psihološko stanje vezano uz posao, a koje obuhvaća čitav niz simptoma, kao što su tjelesni umor, emocionalna iscrpljenost i gubitak motivacije. Sagorijevanje poistovjećuje sa značenjima kao što su: »isprazniti nekog «, »iscrpiti njegove fizičke i mentalne resurse«, »istrošiti ga« zbog pretjeranog nastojanja da se postignu neka nerealna očekivanja, vlastita ili postavljena kroz društvene vrijednosti.

Ubrzo nakon toga, Christina Maslach (1976.) sagorijevanje definira kao višedimenzionalni sindrom stresa koji se sastoji od mentalnog umora (emocionalna iscrpljenost) i negativne percepcije te osjećaja naspram klijenata i pacijenata (depersonalizacija). Nešto kasnije, uvodi i treću komponentu sagorijevanja (Maslach i Jackson, 1981.), koja se odnosi na osjećaj smanjenog osobnog postignuća. O ovim fazama bit će nešto više riječi u nastavku.

Ubrzo nakon prvih radova Maslach (1976.) i Freudenberger (1974.) raste interes za koncept sagorijevanja te se pojavljuje niz autora koji su pokušali dati svoju definiciju ovog sindroma. Tako Edelwich i Brodsky (1980.) sagorijevanje definiraju kao progresivni gubitak ideala, energije, ciljeva i interesa do koji su rezultat uvjeta na poslu. Perlman i Hartman (1982.) definiraju sagorijevanje kao odgovor na kronični emocionalni stres koji ima tri dimenzije: emocionalnu i/ili fizičku iscrpljenost, nisku radnu produktivnost i depersonalizaciju. Sturgess i Poulsen (1983.) definiraju sindrom sagorijevanja kao progresivni gubitak idealizma, energije i smislenosti, kojem su podložniji pojedinci iz pomagačkih profesija. Johnson i Stone (1987.) navode da je sagorijevanje stanje iscrpljenosti koje proizlazi iz povezanosti između klijenata/korisnika i pomagača u emocionalno zahtjevnim situacijama.

Christina Maslach koja se ubraja u najpoznatije istraživače sagorijevanja na poslu, i njezini suradnici, kao što smo ranije naveli, pod ovim pojmom podrazumijevaju tri aspekta: sindrom emocionalne iscrpljenosti, depersonalizacije i smanjenog osobnog postignuća, koji se pojavljuje među pojedincima koji rade s ljudima (Maslach, Jackson i Leiter, 1996.). Emocionalna iscrpljenost odnosi se na osjećaj emocionalne »rastegnutosti $\mathrm{i}$ iscrpljenosti zbog kontakta s drugim ljudima. Kada se emocionalne rezerve iscrpe, čovjek više nije sposoban davati se drugima. U istraživanju u kojem je sudjelovalo 128 socijalnih radnika zaposlenih u službama za mentalno zdravlje u kojem su mjereni faktori sagorijevanja i zadovoljstva poslom, pokazalo se da je veća uključenost u radu s korisnicima koji imaju ozbiljnu mentalnu bolest pozitivno povezana s emocionalnom iscrpljenošću. Rad s korisnicima nije bio u korelaciji sa zadovoljstvom poslom i doživljajem osobnog ispunjenja, dok je rad s teže psihički bolesnim osobama bio u najvećoj korelaciji s emocional- 
nim iscrpljenjem i depersonalizacijom (Acker, 1999.). Autori dalje iznose da socijalni radnici koji sagorijevaju i ne nalaze zadovoljstvo u poslu, češće pružaju »loše« usluge, više izostaju s posla i vjerojatnije daju otkaz. Depersonalizacija se odnosi na bezosjećajan i ravnodušan odnos prema korisncima. Ovaj negativan stav može prerasti u grubo, neosjetljivo ili čak neprilagođeno ponašanje prema njima (dehumanizacija) ili povlačenje od njih (Wills, 1986.). Smanjeno osobno postignuće odnosi se na opadanje osjećaja kompetencije i uspješnog postignuća u radu s ljudima, što može dovesti do ekstremnog osjećaja neadekvatnosti, neuspjeha, gubitka samopoštovanja, pa čak i depresije.

Međutim, nisu svi istraživači suglasni s konceptualizacijom sindroma sagorijevanja kao trodimenzionalnog konstrukta (depersonalizacije, emocionalne iscrpljenosti, smanjenog osobnog postignuća). Primjerice, Lee i Ashforth (1996.) smatraju da emocionalna iscrpljenost i depersonalizacija zajednički vode k osjećaju smanjenog osobnog postignuća, dok ostali istraživači navode da depersonalizacija i osjećaj smanjenog osobnog postignuća predstavljaju posljedice sindroma sagorijevanja, a nikako zasebne dijelove konstrukta.

Manzano-García i Ayala-Calvo (2013.), analizirajući definicije sagorijevanja od pojave ovog koncepta do danas, navode kako su one komplementarne, a ne u međusobnim proturječjima, te da ih se može grupirati ovisno o tome sagledava li se sagorijevanje kao stanje ili proces.

Usprkos individualnim razlikama među ljudima, postoji niz istih znakova sagorijevanja. Tako Ajduković (1996.a) znakove sagorijevanja grupira u tri kategorije. To su: 1) tjelesna iscrpljenost, koja je popraćena snažnim osjećajem istrošenosti, uz koji se često javljaju poteškoće spavanja, osjećaj pomanjkanja energije, kronični umor i slabost; uzrok tome su ograničene snage pojedinca i dugotrajna izloženost stresu; 2) emocionalna iscrpljenost, gdje su emocionalne rezerve pojedinca smanjene i iscrpljene, a sagorjeli pomagač očituje osjećaje bespomoćnosti, beznadnosti, besmislenosti i depresivnosti te mu je životno zadovoljstvo općenito smanjeno; 3) mentalna iscrpljenost, koja se očituje se kao negativan stav prema poslu, korisnicima i kolegama. Javlja se tzv. dehumanizacija, odnosno emocionalno udaljavanje od korisnika i kolega, a osjećaj negativizma i emocionalne udaljenosti može se »preliti« i u privatno područje života.

Sindrom sagorijevanja na poslu je kumulativan proces koji ima svoje faze. Tako Brown i Bourne (1996.) navode da proces sagorijevanja na poslu karakterizira veliki početni entuzijazam, u kojem pomagač ne koristi nikakvu »emocionalnu zaštitu«, nakon čega postaje ranjiv, emocionalno se povlači, gubi interes, počinje okrivljavati druge, postaje ciničan i naposljetku »kolabira«. Ajduković (1996.a) navodi četiri ključne faze koje vode do sagorijevanja. Prva faza je faza radnog entuzijazma koju karakteriziraju nerealna očekivanja brzog postignuća, preveliko ulaganje u posao i

\section{4 članci}


nekritična predanost poslu. U ovoj fazi pomagač radi mnogo dulje od uobičajenog radnog vremena. Raskorak između uloženog profesionalnog napora i njegovih učinaka često dovodi do osobnog razočaranja i prvih znakova bespomoćnosti. Druga je faza stagnacije kad pomagač postane svjestan da postignuće u poslu nije onakvo kakvim ga je zamišljao. To dovodi do stanja frustracije, osjećaja razočaranja, dvojbe u vlastitu kompetentnost, pojavu negativizma i do poteškoća u komuniciranju kako s kolegama tako i sa korisnicima. Emocionalna ranjivost pomagača je karakteristika ove faze. Treća je faza emocionalnog povlačenja i izolacije koja se očituje udaljavanjem od korisnika i kolega što doprinosi doživljaju posla kao besmislenog i nevrijednog. Proces sagorijevanja ubrzavaju i tjelesne poteškoće koje se javljaju u ovoj fazi (glavobolje, kronični umor, nesanica, alergije i sl.). I sami znaci sagorijevanja počinju pomagaču predstavljati dodatne stresore te ga dovode do posljednje faze sagorijevanja na poslu. Posljednja je faza apatije i gubitka životnih interesa. Ona se javlja se kao svojevrsna obrana od kronične frustriranosti na poslu. Početno suosjećanje i entuzijazam u ovoj fazi zamijenjeni su cinizmom ili ravnodušnošću prema problemima korisnika. Znaci depresije kod pomagača postaju jasno uočljivi, a motivacija za posao i osobni resursi potpuno su iscrpljeni. Sagorijevanje na poslu kao istraživački problem ubraja se u interdisciplinarno područje istraživanja stresa, odnosno stresa u radu. Pregled znanstvene literature i istraživanja pokazuje da se profesionalnom stresu i sagorijevanju počela pridavati pažnja u ranim 1980im godinama (Cherniss, 1980.; Freudenburger i Richelson, 1980.; Maslach i Jackson, 1981., 1986.) te da profesionalci izloženi stresu u radnom okruženju mogu osjećati tjeskobu, depresiju, sagorijevanje i druge fizičke i mentalne poteškoće. Istraživanja u 1990-ima počinju se baviti utjecajem stresa na poslu, ulogom sukoba, sagorijevanjem na različitim razinama, primjerice, utjecajem na osobne i bračne odnose i dr., pojedinačnim čimbenicima koji doprinose sagorijevanju. Noviji istraživači više su se bavili organizacijskim, strukturnim i drugim faktorima koji doprinose zadovoljstvu na poslu te su bili više usmjereni na pozitivne aspekte (Bednar, 2003.).

Sagorijevanje se, dakle, događa onda kada posao za osobu izgubi smisao. U takvim situacijama ljudi nisu motivirani za rad, gube svako zadovoljstvo u poslu, ne vide razlog za daljnji rad, što dovodi do pada produktivnosti te u konačnici i mogućeg napuštanja posla. Tako Farber (1983.: 3) navodi kako »sagorjeli profesionalci češće izostaju s posla ili kasne na posao u odnosu na njihove nesagorjele kolege, oni postaju značajno manje idealistični i više rigidni, njihova učinkovitost na poslu se značajno smanjuje i razmišljaju ili čak planiraju napuštanje te profesije«. Istraživanja pokazuju da ti pojedinci pate od visoke razine stresa i niskog zadovoljstva poslom, pri čemu je veza između stresa i (ne)zadovoljstva poslom u radnom okruženju ključna za sagorijevanje (Barrick, 1989.). 
Maslach i Jackson (1981., 1986.) navode da je sagorijevanje na poslu češće prisutno kod zdravstvenih djelatnika i profesionalaca koji imaju pacijente i klijente $s$ kojima su u svakodnevnom kontaktu te uzroke pronalaze prije svega u faktorima vezanima uz radno okruženje. S druge strane, Freudenberger (1974.) naglašava važnost osobnih obilježja pojedinaca koja doprinose sagorijevanju.

Istraživanjem provedenim sa 600 američkih radnika različitih profesija utvrđeno je da je velik broj radnika doživljavao stres i da je pokazivao simptome sagorijevanja. Primijećeno je da su ovi radnici imali smanjenu produktivnost, više izostanaka s posla, veće troškove liječenja i da su češće mijenjali radna mjesta. Također je primijećeno da je sagorijevanje bilo više izraženo kada su se ukidale povoljnosti na poslu, kada se zahtijevao prekovremeni rad i kada se mijenjalo vodstvo tvrtke (Employee Bornout, 1991., prema Felton, 1998.).

Provjerom profesionalnog stresa i njegova utjecaja na fizičko zdravlje, psihološku dobrobit i zadovoljstvo poslom između 26 skupina različitih zanimanja u Velikoj Britaniji (zbog usporedbe stresnosti posla), pokazalo se da šest skupina ima značajno veću podložnost negativnim posljedicama stresa (Johnson i sur., 2005.). To su: zdravstveni radnici, nastavnici, socijalni radnici, djelatnici u pozivnim centrima, policajci i zatvorski čuvari. Dakle, dobiveni rezultati pokazuju da je ovih šest skupina, kada se uzmu u obzir tri mjere posljedica stresa (fizičko zdravlje, psihološka dobrobit i zadovoljstvo poslom), u značajno većem riziku od negativnih posljedica stresa. Svako od navedenih zanimanja uključuje emocionalnu komponentu rada koja je relevantna za doživljaj stresa na poslu (Zapf, 2002.). I različite druge studije pokazuju da su osobe koje se bave tzv. pomažućim profesijama, kao što su socijalni radnici i medicinske sestre (Kahn, 1993.; Cooper, Dewe i O’Driscoll, 2001.) psiholozi (Mills i Huebener 1998.), nastavnici (Travers i Cooper, 1993.) i policajci (Waters i Ussery, 2007.), podložnije stresu, odnosno sagorijevanju.

Stoga ćemo se u nastavku posvetiti istraživanjima o sagorijevanju na poslu kod socijalih radnika, s obzirom se radi o jednoj od najrizičnijih profesionalnih skupina s obzirom na sagorijevanje.

\section{Sindrom sagorijevanja na poslu kod socijalnih radnika}

lako dosadašnja istraživanja pokazuju da socijalni radnici mogu postići značajno zadovoljstvo u radu, oni imaju tendenciju doživjeti višu razinu stresa i sagorijevanja na radnom mjestu od mnogih drugih profesionalnih skupina (Lloyd, King i Chenoweth, 2002.; Johnson i sur., 2005.; Collins, 2008.). Stres na radnom mjestu ima ozbiljne implikacije za psihičku i fizičku dobrobit socijalnih radnika i njihovo daljnje profesionalno funkcioniranje (Coffey, Dugdill i Tattersall, 2009.) Zanimljiva

\section{6 članci}


je studija Curtis, Moriarty i Netten (2010.) koji su utvrdili da je životni vijek socijalnog radnika znatno manji (oko osam godina) od nekih drugih pomagačkih profesija, poput liječnika ili medicinskih sestara. Priroda posla, odnosno visoka razina stresa i sagorijevanja koje socijalni radnici doživljavaju u svome radu, jedan je od najčešćih razloga napuštanja struke.

Evans i sur. (2006.) su istraživanjem u kojem je sudjelovalo 237 socijalnih radnika iz Velike Britanije, utvrdili da $47 \%$ njih ima teškoće, odnosno iskazuje zabrinutost zbog svog mentalnog zdravlja, dok je Siebert (2005.) ustanovio da 39\% socijalnih radnika doživljava sagorijevanje na poslu. Jones i Novak (1993.) navode da je značajan doprinos sagorijevanju problem administrativnih i financijskih poteškoća koje imaju socijalni radnici u socijalnim službama pri čemu su »gurnuti u antagonistički odnos s klijentima, demoralizirani i bez jasnog smjera«. Povezano s tim, kao i drugim negativnim uvjetima, sagorijevanje na poslu postalo je značajan problem u socijalnim službama. Meyerson (1994.) je kod proučavanja profesionalne kulture socijalnih radnika ustanovila da su simptomi sagorijevanja interpretirani kao nešto sasvim normalno i da sa sobom nose značaj predanog stručnjaka.

$\mathrm{U}$ jednom relativno novijem istraživanju (Musa, 2009.) ispitivana je zastupljenost sekundarnog traumatskog stresa, sagorijevanje i njegov utjecaj na zadovoljstvo poslom kod 180 socijalnih radnika koji rade u sustavu socijalne skrbi, školama, bolnicama i nevladinim organizacijama u Ujedinjenim Emiratima. Rezultati su pokazali da je dob negativno povezana sa sagorijevanjem i sekundarnim traumatskim stresom, a pozitivno povezana s osjećajem umora. Sagorijevanje je povezano s radnim mjestom socijanih radnika s obzirom da je utvrđeno da postoje značajne razlike u odnosu na radna mjesta na kojima su zaposleni. Tako su školski socijalni radnici nezadovoljni poslom, dok su socijalni radnici zaposleni unutar sustava socijalne skrbi izloženi visokom riziku sagorijevanja na poslu.

Činitelji koji doprinose sindromu sagorijevanja mogu biti različiti. Tako, primjerice, Arches (1991.) te Poulin i Walter (1993.) ukazuju da sagorijevanju doprinosi nedostatak autonomije u radu, konflikt uloga, neadekvatna opremljenost radnog mjesta i nedostatak socijalne podrške. Također, sagorijevanju doprinosi i nedostatak edukacije, komunikacije i podrške osoblja te kada se većina vremena provodi u administrativnim poslovima (Cherniss, 1980.).

Kada govorimo o hrvatskom kontekstu, istraživanja o sagorijevanju na poslu kod socijalnih radnika relativno su malobrojna, ali su nešto češća u posljednjih nekoliko godina. Zanimljivo je usporediti četiri istraživanja koja su provedena na području Hrvatske unutar kojih je korišten mjerni instrument autora Ajduković i Ajduković (1994.), Upitnik intenziteta sagorijevanja na poslu. Prvo istraživanje u kojem je korišten ovaj upitnik, proveli su Ljubotina i Družić (1996.) u okviru Društva za psihološku pomoć, a cilj je bio utvrditi stupanj sagorijevanja na poslu i faktore 
koji su povezani s razinom sagorijevanja. U istraživanju je sudjelovalo 283 »pomagača« različitih profesija (socijalni radnici, psiholozi, defektolozi, zdravstveni djelatnici, prosvjetni radnici i dr.). Na Upitniku intenziteta sagorijevanja na poslu raspon rezultata iznosi od 18 (nema sagorijevanja) do 54 (maksimalno sagorijevanje), pri čemu Ljubotina i Družić (1996.) kategoriziraju rezultate u tri skupine. Rezultate od 18 do 25 svrstavaju u kategoriju »bez znakova sagorijevanja«, rezultate od 26 do 33 u kategoriju "početno sagorijevanje«, a rezultate u rasponu od 34 do 54 svrstavaju u kategoriju »visokog stupnja sagorijevanja«. Sudionici ovog istraživanja bili su pomagači koji su u vrijeme istraživanja (1995. godine) bili najvećim dijelom orijentirani na rad sa stradalnicima rata te je to bio kontekst unutar kojeg su se i okupili na seminarima koje je tada provodilo Društvo za psihološku pomoć. Ustanovljeno je da je prosječna ocjena na upitniku sagorijevanja $M=28,7$, što je ukazivalo da je najveći broj sudionika u kategoriji »početnog sagorijevanja«, dok je njih $18,1 \%$ iskazivalo visok stupanj sagorijevanja. Također je utvrđeno da nema razlike u sagorijevanju između socijalnih radnika i ostalih pomagača te da je sagorijevanje na poslu povezano s osobinama pomagačke uloge, što znači da je percepcija veće prisutnosti problema u obavljanju pomagačke uloge povezana sa sagorijevanjem. U ovom se istraživanju pokazalo i da postoji veći stupanj sagorijevanja kod pomagača mlađe dobi i pomagača zaposlenih u vladinim organizacijama (u odnosu na nevladine). Pet tvrdnji, odnosno znakova sagorijevanja koji su, prema aritmetičkim sredinama, bili najviše rangirani su redom: Osjećam se nemoćnim promijeniti nešto na poslu., Frustracije izazvane poslom unosim i u privatni život., Razdražljiviji sam nego ikad prije., Imam teškoća u organiziranju svog posla i vremena., Na poslu se osjećam umorno i iscrpljeno čak $i$ kada sam dobro naspavan.

Slične nalaze na istom upitniku sagorijevanja dobila je i Friščić (2006.) koja je provela istraživanje u kojem je sudjelovalo 147 socijalnih radnika iz Centra za socijalnu skrb Zagreb. Prosječna ocjena na upitniku sagorijevanja bila je $M=29,1$, čime je također utvrđeno da je najveći broj sudionika bio u kategoriji početnog sagorijevanja, a njih je $11,5 \%$ iskazivalo visok stupanj sagorijevanja na poslu. $U$ ovom se istraživanju pokazalo da socijalni radnici koji dnevno rade s većim brojem korisnika iskazuju u većoj mjeri prisutnost postojanja psihosomatskih smetnji, što također vrijedi i za socijalne radnike koji iskazuju visok rezultat na Upitniku intenziteta sagorijevanja na pos/u. Rezultati regresijske analize pokazali su da su sa sindromom sagorijevanja na poslu povezani sljedeći faktori: izloženost verbalnoj agresiji klijenta, izloženost fizičkim napadima klijenta, preopterećenost poslom i osjećaj prevelike odgovornosti u donošenju važnih odluka za klijenta. Unutar istog istraživanja kod socijalnih radnika koji iskazuju znakove sagorijevanja, identificirani su stresogeni čimbenici kao što su: nedovoljna educiranost za rad u odnosu na specifične probleme klijenta, loša organizacija unutar ureda, poslovi koji ne spadaju u opis rad-

\section{8 članci}


nog mjesta, izloženost fizičkim napadima klijenata, nejasna pravila nagrađivanja, izloženost verbalnoj agresiji klijenata, nemogućnost izražavanja vlastite kreativnosti, česta izloženost kritikama javnosti, nemogućnost udovoljavanja zahtjevima korisnika zbog objektivnih razloga, česte promjene zakonskih regulativa, izostanak podrške kolega, loš odnos s kolegama u timu, nemogućnost profesionalnog usavršavanja, osjećaj prevelike odgovornosti u donošenju važnih odluka za klijente te preopterećenost poslom (rokovi, velik broj klijenata).

Istraživanje Panić (2011.) u kojem je jedan od istraživačkih problema bio utvrditi razlike u sagorijevanju na poslu kod djelatnika MUP-a, profesionalnih vatrogasaca i socijalnih radnika zaposlenih u CZSS-u, ustanovljeno je da su socijalni radnici na Upitniku intenziteta sagorijevanja na poslu iskazali viši rezultat $(M=27,2)$ u odnosu na djelatnike MUP-a $(M=25,5)$ i profesionalne vatrogasce $(M=23,7)$. Utvrđene su značajne razlike između subuzoraka gdje se pokazalo da skupina djelatnika CZSS-a postiže statistički značajno veći prosječni rezultat na Upitniku intenziteta sagorijevanja na poslu od skupine vatrogasaca, a djelatnici MUP-a ne razlikuju se značajno niti od jedne skupine. Analizirajući aritmetičke sredine kod socijalnih radnika u ovom istraživanju u usporedbi s prethodna dva, moguće je zaključiti da se i ovdje pokazalo kako socijalni radnici iskazuju početne i relativno blage znakove sagorijevanja. U ovom istraživanju, jednako kao i u istraživanju koje je provedeno 1995. godine (Ljubotina i Družić, 1996.), najviše rangirana tvrdnja (prema aritmetičkoj sredini) bila je: Osjećam se nemoćnim promijeniti nešto na poslu. Nakon nje slijedile su tvrdnje: Na poslu se osjećam umorno i iscrpljeno čak i kada sam dobro naspavan., Frustracije izazvane poslom unosim i u privatni život., Razdražljiviji sam nego ikad prije. te Čini se da nikog na poslu nije briga za ono što radim.

Moštak Skupnjak (2012.) je u svojem istraživanju o sagorijevanju na poslu kod socijalnih radnika (provedenom 2007. godine) također koristila Upitnik intenziteta sagorijevanja na poslu. U njemu je sudjelovalo 177 socijalnih radnika zaposlenih u sustavu socijalne skrbi na području Grada Zagreba i Zagrebačke županije. Od navedenog broja sudionika, njih 127 bilo je iz centara za socijalnu skrb, a 50 iz drugih ustanova socijalne skrbi (dječji domovi, ustanove za djecu s teškoćama u razvoju, ustanove za djecu s poremećajima u ponašanju, domovi za stare i nemoćne osobe i zavodi za socijalno zdravstvenu zaštitu). Prosječni rezultat na Upitniku sagorijevanja na poslu iznosio je $M=26,6$. Rezultati su pokazali da socijalni radnici zaposleni u centrima za socijalnu skrb iskazuju početne znakove sagorijevanja $(M=27,6)$ za razliku od socijalnih radnika zaposlenih u drugim ustanovama socijalne skrbi koji ne pokazuju znakove sagorijevanja $(M=24,3)$. I u ovom istraživanju je najviše rangirana čestica: Osjećam se nemoćnim promijeniti nešto na pos/u., a slijede ju tvrdnje: Razdražljiviji sam nego ikad prije., Na poslu se osjećam umorno i iscrpljeno čak i kada sam dobro naspavan., Frustracije izazvane poslom unosim i u privatni život., Čini se da 
nikog na poslu nije briga za ono što radim. U 13 tvrdnji unutar Upitnika intenziteta sagorijevanja na pos/u, socijalni radnici zaposleni u centrima za socijalnu skrb iskazuju dosljedno veći intenzitet sagorijevanja na poslu. Najveće razlike između socijalnih radnika zaposlenih u centrima za socijalnu skrb i onih zaposlenih u drugim ustanovama socijalne skrbi su u sljedećim tvrdnjama: Osjećam da postižem manje nego ikad prije., Mislim negativno o poslu i usmjeravam se na njegove loše strane., Više nego ikad svjesno izbjegavam osobne kontakte., Razdražljiviji sam nego prije., Imam teškoća u organiziranju svog posla i vremena.

$\mathrm{Na}$ osnovi analize ova četiri istraživanja provedena sa socijalnim radnicima u Hrvatskoj, u razdoblju od 18 godina, vidljivo je da se prosječna ocjena na Upitniku intenziteta sagorijevanja na poslu kretala u rasponu od $M=26$ do $M=29$, što bi ukazivalo na to da većina socijalnih radnika iskazuje početne znakove sagorijevanja na poslu. Pritom je iz prikazanih istraživanja moguće zaključiti da su socijalni radnici zaposleni u centrima za socijalnu skrb u većem riziku od sagorijevanja. To ide u prilog često navođenoj činjenici o složenosti posla socijalnog radnika u centrima za socijalnu skrb, koji uključuje već spomenutih oko 140 nadležnosti, iz čega proizlazi i iznimno visok stupanj odgovornosti ovih stručnjaka u odnosu na brojna postupanja i odluke koje trebaju donijeti vezano uz teškoće na koje nailaze korisnici centra. Iz analize ova četiri domaća istraživanja uočljivo je da je konzistentno najviše rangirani simptom sagorijevanja vezan uz osjećaj nemoći u mogućnosti utjecaja na neke promjene na poslu (Osjećam se nemoćnim promijeniti nešto na poslu.). Što nam govori taj podatak? Moguće je zapitati se kako je to raditi na tako odgovornom radnom mjestu u kojem se donose važne odluke vezane uz ljudske sudbine, a na kojem stručnjak ima osjećaj da ne može utjecati na promjene na svom poslu. Poznato je da je osjećaj bespomoćnosti, odnosno nemogućnosti utjecaja na određene promjene u nekom važnom segmentu života, povezan s osjećajem frustracije, ljutnje, rezignacije, apatije i u konačnici - depresije. Potrebno je zapitati se kako se to može odraziti na rezultate rada, odnose s korisnicima, kolegama, nadređenima, privatni život i mentalno zdravlje djelatnika. Ono što je sve vidljivije u današnjem trenutku jest da socijalni radnici sve više iskazuju svoje nezadovoljstvo vezano uz nemogućnost utjecaja u svom profesionalnom okruženju; od donošenja zakonskih regulativa, pa sve do konkretnog postupanja prema korisnicima, s obzirom na čestu neprilagođenost sustava i zakona potrebama korisnika (Kovačić, 2003.), kao i zbog konflikta stručnog i administrativnog rada te nejasnih profesionalnih uloga (Jeleč Kaker, 2009.). To je konstanta koja vjerojatno nije vezana samo uz današnji trenutak socijalne i ekonomske krize, koja se odrazila na brojne segmente života, jer su prikazana istraživanja unazad 18 godina. Činjenica jest da socijalni radnici nemaju osobit utjecaj u donošenju zakonodavnih okvira koji se tiču prirode njihovog posla, te da neke druge profesije, odnosno politike »kroje«

\section{0 članci}


okvire njihovog djelovanja. S druge pak strane, u habitusu profesije socijalnog rada je težnja za promjenama, što je ugrađeno i u određenje profesije socijalnog rada. Međunarodno udruženje škola socijalnog rada (IASSW, 2014.) tako definira socijalni rad kao profesiju koja promiče socijalnu promjenu i razvoj, socijalnu koheziju i osnaživanje ljudi.

To je u skladu s ranije spomenutim istraživanjima Arches (1991.) i Poulin i Walter (1993.) koja ukazuju da je sagorijevanje povezano s osjećajem nedostatka autonomije, ali i konfliktom uloga. Naime, konflikt uloga, kada govorimo o profesiji socijalnog rada, očito predstavlja sastavni dio profesionalnog djelovanja, jer je često istican kao problem socijalnih radnika ne samo kod nas, nego i u svijetu. Teško se može očekivati da će generatori promjene biti socijalni radnici unutar državnih institucija, prije svega zbog njihove zavisne pozicije koja u sebi sadrži i dvostrukost uloge. S jedne strane, radi se o državnim službenicima koji provode zakonske odredbe koje su donijela državna tijela, te se nalaze u ulozi »zaštitnika« sustava. S druge pak strane, oni su zagovaratelji prava svojih korisnika, oni koji trebaju djelovati po načelima profesije i ponekad nailaze na zakonske i administrativne »zidove« ili se nalaze u poziciji nemoći nešto promijeniti i postupati prije svega iz pozicije zagovaratelja prava korisnika, jer su ograničeni tim istim zakonskim i birokratskim regulativama. U posljednjih nekoliko godina sve se više govori o ovoj dvostrukosti uloga koje ponekad bivaju nepomirljive i mogu dovesti do osjećaja bespomoćnosti i frustriranosti (Družić Ljubotina, 2013.).

Na osnovi prethodno prikazanih istraživanja, vidljivo je da socijalni radnici nakon osjećaja nemoći, kao najviše zastupljene znakove sagorijevanja nadalje iskazuju: umor i iscrpljenost, razdražljivost, frustriranost koja se unosi i u privatni život te osjećaj usamljenosti (nikoga nije briga za ono što radim).

Vratimo li se na kategorizaciju znakova sagorijevanja koje navodi Ajduković (1996.), možemo zaključiti da je kod hrvatskih socijalnih radnika na samom vrhu prisutan simptom vezan uz emocionalnu iscrpljenost, s obzirom da je osjećaj nemoći ili bespomoćnosti najviše zastupljen znak u svim navedenim istraživanjima u Hrvatskoj. Zatim je na vrlo visokom mjestu prisutna kategorija tjelesne iscrpljenosti, s obzirom na visoku zastupljenost umora i iscrpljenosti. No, i znakovi koji se mogu ubrojiti u treću kategoriju, a to je mentalna iscrpljenost, također su značajno zastupljeni s obzirom na visoko prisutan osjećaj veće razdražljivosti, ali i frustriranosti koja ugrožava privatni život te osjećaj usamljenosti u obavljanju profesionalne uloge.

Postavlja se pitanje na koji način pristupiti ovim rezultatima. Treba li se zabrinuti ili odahnuti što socijalni radnici u Hrvatskoj iskazuju početni stadij sagorijevanja na poslu? Da li to prihvatiti kao prirodno stanje stvari jer se radi o profesiji čiji je sastavni dio baviti se, prije svega, problemima i potrebama različitih kategorija lju- 
di? Ili je ovaj podatak poziv na uzbunu i potrebu promišljanja unapređenja pozicije socijalnih radnika, kako u organizacijskom smislu, tako i u smislu zaštite mentalnog zdravlja ovih stručnjaka? Naše je mišljenje da, iako su mnoga istraživanja pokazala da se radi o profesiji koja je zbog prirode pomagačkog posla podložnija sagorijevanju na poslu, treba ozbiljno shvatiti dobivene nalaze i isto tako ozbiljno se posvetiti zaštiti i očuvanju mentalnog zdravlja socijalnih radnika.

\section{Suzbijanje profesionalnog stresa i sagorijevanja kod socijalnih radnika}

Kao što smo nekoliko puta napomenuli, profesionalni stres u djelatnosti koju obavljaju socijalni radnici teško je u potpunosti izbjeći, s obzirom da ovi stručnjaci svakodnevno rade s ljudima koji se nalaze u brojnim životnim teškoćama i pritom imaju iznimno odgovornu poziciju, donoseći neke ključne odluke u životima njihovih korisnika. Postavlja se pitanje kako izbjeći negativne posljedice profesionalnog stresa, kao što je, primjerice, sagorijevanje. Je li moguće nekako utjecati na ublažavanje izvora stresa u poslu socijalnih radnika? Od samog stupanja socijalnog radnika na radno mjesto, potrebno je raditi na prevenciji pojave profesionalnog stresa i sagorijevanja. Prethodno prikazana istraživanja pokazala su da se socijalni radnici često susreću s izvorom stresa koji se odnosi na nejasno definirane uloge koje obavljaju. Stoga je nužno postojanje stručnog i podržavajućeg mentorstva koje podrazumijeva jasno definiranu ulogu, očekivanja i ciljeve od pretpostavljenih (Jeleč Kaker, 2009.; Moštak Skupnjak, 2012.), kao i donošenje pravilnika unutar kojih će biti jasno definirana uloga socijalnog radnika na određenom radnom mjestu/poziciji. Na taj način izbjeći će se i visoko prisutan stresor koji se odnosi na radnu preopterećenost, koja jednim dijelom proizlazi i iz nejasno definiranih uloga koje podrazumijevaju bavljenje »svim i svačim«. Također, da bi se izbjegla radna preopterećenost, koja predstavlja snažan izvor stresa za socijalne radnike, a koji može značajno pridonijeti sagorijevanju na poslu, potrebno je konačno uvesti realne normative rada koji će omogućiti socijalnim radnicima da se kvalitetno posvete svim svojim korisnicima. Poznato je da su socijalni radnici već dugi niz godina podložni nerealnim normativima, što znači da su preplavljeni korisnicima kojima se ne mogu dovoljno kvalitetno posvetiti s obzirom na njihovu brojnost, a s druge strane to podrazumijeva i ažurnost u ispunjavanju administrativno-birokratskih zahtjeva od strane poslodavca, te im i to otežava obavljanje profesionalne uloge za koju su educirani. Naravno, uz to je vezana i nedovoljna kadrovska zastupljenost, osobito u centrima za socijalnu skrb, što je opće poznata činjenica, pri čemu su financijska ograničenja glavni argument poslodavca za takvo stanje. Važno je ponovno se

\section{2 članci}


prisjetiti razloga zbog kojih se socijalni radnici opredjeljuju za svoj poziv. Socijalni rad prije svega počiva na humanističkim i altruističnim vrijednostima, i ljudi koji se opredjeljuju za ovaj poziv, to najčešće čine zbog potrebe da pomognu ljudima koji se nalaze u određenim životnim teškoćama. Nije rijetkost da se, osobito ako se zaposli unutar određenog državnog sustava (socijalne skrbi, zdravstva, pravosuđa), nakon početnog entuzijazama i očekivanja temeljenih na vrijednostima profesije, socijalni radnik suočava s neispunjenim očekivanjima, što može doprinijeti nezadovoljstvu i stresu na poslu (Lait i Wallace, 2002.). Iz prethodno prikazanih istraživanja vidljivoje da socijalni radnici, kao značajan izvor stresa prepoznaju nedostatak socijalne podrške, kako od strane kolega, tako i od nadređenih. Prema McAuliffe (2005.), ishodi profesionalnog stresa mogu se smanjiti ili povećati ovisno o mreži podrške unutar radne organizacije. Kvalitetan odnos s drugima, suradnicima, nadređenim i podređenim unutar organizacije jedan je od glavnih činitelja prevencije stresogenosti pomagačkog zanimanja. Stoga je nužno uspostavljanje kvalitetnih odnosa s kolegama koji će omogućiti ugodnu klimu na radnom mjestu (Jeleč Kaker, 2009.). Način na koji je to moguće postići je prije svega osvještavanje važnosti njegovanja dobrih profesionalnih odnosa unutar radnog okruženja, što prije svega treba biti zadatak voditelja organizacije. Naime, činjenica je da se međuljudskim odnosima u profesionalnoj sredini još uvijek ne posvećuje osobito velik značaj, što je slučaj i kod pomagača pa nije čudno da je odnos s drugima unutar pomagačkih organizacija značajan faktor burnout-a (Ajduković, 1996.). Collins (2013.) na istom tragu navodi kako se socijalni radnici ne mogu adekvatno razvijati bez odgovarajuće podrške kolega i supervizora, ali i pruženih prilika za profesionalni rast i razvoj. Također naglašava da je iznimno važno da socijalni radnici imaju svijest o tome da posjeduju dragocjena znanja i vještine te da imaju osjećaj kontrole u poslu kojim se bave jer je to put prema većoj posvećenosti pozivu koji obavljaju i većem zadovoljstvu na poslu.

Ako se vratimo na istraživanja o sagorijevanju socijalnih radnika provedenih u Hrvatskoj (Ljubotina i Družić, 1996.; Friščić, 2006.; Panić, 2011.; Moštak Skupnjak, 2012.), kao izražen simptom sagorijevanja na poslu se pojavljuje tvrdnja: Čini se da nikog na poslu nije briga za ono što radim. Ovaj znak sagorijevanja moguće je povezati s izraženim izvorima profesionalnog stresa kod socijalnih radnika kao što su nedostatak socijalne podrške i loši odnosi u timu, ali i s osjećajem profesionalne usamljenosti. Svi ovi pokazatelji jasno upućuju na važnost pridavanja pažnje međuljudskim odnosima u radnom okruženju, kao i povratnim informacijama o radu i rezultatima rada. U skladu s tim, Ajduković (1996.b) navodi četiri osnovna tipa profesionalnog dijaloga koji pomažu pomagačima u profesionalnom djelovanju. To su: supervizija, konzultacije, sažeto psihološko integriranje traumatskog doživljaja i psihološko savjetovanje. Supervizija kao oblik stručne pomoći pomagaču može 
omogućiti otvoreno iznošenje svojih problema i osjećaja vezanih uz rad. lako se već godinama govori o potrebi uvođenja redovite supervizije u sustav socijalne skrbi te u Zakonu o socijalnoj skrbi (NN, 33/14) stoji da stručnjaci zaposleni u sustavu socijalne skrbi imaju pravo i obvezu sudjelovanja na superviziji, ona još uvijek nije sustavno zaživjela u nas.

S ciljem suzbijanja izvora stresa i prevencije sagorijevanja, osim predloženih mjera i poteza na strukturalnoj razini, neki autori predlažu i određene mjere samopomoći s ciljem očuvanja mentalnog zdravlja pomagača. Jedan od njih je često citirani Goliszek (1993.) koji predlaže, kao zdrave načine suočavanja sa stresom sljedeće tehnike samopomoći: izraziti osjećaje, rasporediti vrijeme, prepoznati granice energije, ne planirati više od jedne stresne aktivnosti u isto vrijeme, baviti se fizičkom aktivnošću, raspodijeliti odgovornost, raspodijeliti posao na manje dijelove, naučiti reći »ne«, poboljšati radne vještine, nastojati uspjeti i naučiti se relaksirati. Na tragu preporuka koje pojedinac može poduzeti kako bi spriječio sagorijevanje na poslu Leiter i Maslach (2011.) razrađuju šest strategija »za poboljšanje odnosa s poslom« koje proizlaze iz šest glavnih poteškoća s kojima se ljudi susreću na svom radnom mjestu. To su strateška područja koje se odnose na: preveliko radno opterećenje, nedostatak kontrole u obavljanju profesionalne usluge, nedovoljno nagrađivanje, odnosno nedostatak priznanja za rad, teškoće u socijalnoj okolini (podijeljenost, problem u komunikaciji ili otuđenost), nepravdu (nepoštovanje, diskriminacija ili protekcija) te neusklađenost na razini vrijednosti (nepoštenje, besmislenost). Za svako od navedenih šest područja, autori nude akcijski plan koji se bazira na četiri koraka: definirati problem, postaviti ciljeve, poduzeti akciju i bilježiti napredak. Naravno, pritom naglašavaju kako je akcijski plan prije svega dugotrajan proces, a ne brzo rješenje, te zahtijeva vrijeme, napor i posvećenost.

\section{ZAKLJUČAK}

Na osnovi prikazanih istraživanja o izvorima stresa i sagorijevanju na poslu kod socijalnih radnika moguće je zaključiti da postoje određene konzistentnosti u nalazima. Nedvojbeno je da je ova profesija jedna od najizloženijih stresu na radu i sagorijevanju, na što upućuju brojna ranije navedena istraživanja, kako u svijetu, tako i kod nas. $U$ hrvatskom kontekstu, istraživanja su pokazala kako se većina socijalnih radnika nalazi u početnom stadiju sagorijevanja. Kao najčešći izvori stresa pojavljuju se faktori vezani uz radno opterećenje, nedostatak vremena, nejasno definirane uloge, nedovoljnu socijalnu podršku, osjećaj nesigurnosti i izloženosti na radnom mjestu, kao i problem balansiranja između radne i profesionalne uloge.

Simptomi sagorijevanja na poslu, koji su najviše prisutni kod socijalnih radnika, odnose se prije svega na emocionalnu iscrpljenost i to na osjećaj nemoći u utjecaju

\section{4 članci}


na promjene na poslu. Ovaj nalaz mogao bi biti povezan s nedostatkom kontrole i autonomije pri obavljanju profesionalne uloge, što bi svakako bilo dobro istražiti i u našem kontekstu. Također, izrazito su prisutni tjelesni simptomi sagorijevanja, kao što su umor i iscrpljenost, ali i mentalna iscrpljenost, koja se odnosi primarno na osjećaj frustriranosti koja se prenosi na privatni život te na osjećaj usamljenosti.

Zbog svega navedenog, neophodna je briga nadležnih institucija o mentalnom zdravlju svojih djelatnika jer je na taj način moguće pridonijeti boljim učincima u radu socijalnih radnika, a što će, dugoročno gledano, dovesti do poboljšanja kvalitete u području socijalnog rada, kao i općenito do unapređenja ove djelatnosti. Očekivano bi bilo da nadležna tijela prepoznaju vrijednosti i identificiraju poteškoće svojih djelatnika, pružajući im jasne informacije o procedurama rada institucije i omogućavaju supervizije, edukacije i odgovarajuću autonomiju. Socijalni radnici trebali bi slijediti te standarde, napredovati i razvijati se. Kombinacijom ovih elemenata zajedno, poboljšala bi se podrška i motivacija, što bi doprinijelo boljoj kvaliteti rada, a time i napretku sustava socijalne skrbi, u kojem je zaposlen najveći broj socijalnih radnika. Brigom za mentalno zdravlje i zadovoljstvo poslom kod socijalnih radnika i ostalih pomagača koji se bave socijalnom skrbi, direktno se djeluje i na veću posvećenost i kvalitetu u radu stručnjaka s neposrednim korisnicima.

\section{LITERATURA}

1. Acker, G. M. (1999). The impact of clients' mental illness on social workers' job satisfaction and burnout. Health and Social Work, 24 (2), 112-119.

2. Ajduković, D. \& Ajduković, M. (ur.) (1996). Zašto je ugroženo mentalno zdravlje pomagača? Pomoć i samopomoć u skrbi za mentalno zdravlje pomagača. Zagreb: Društvo za psihološku pomoć, 3-10.

3. Ajduković, D. (1996). Izvori profesionalnog stresa i sagorijevanja pomagača. U: Ajduković, D. \& Ajduković, M. (ur.), Pomoć i samopomoć u skrbi za mentalno zdravlje pomagača. Zagreb: Društvo za psihološku pomoć, 29-37.

4. Ajduković, M. \& Ajduković, D. (1994). Upitnik intenziteta sagorijevanja na poslu. Zagreb: Društvo za psihološku pomoć.

5. Ajduković, M. \& Urbanc, K. (2010). Kvalitativna analiza iskustva stručnih djelatnika kao doprinos evaluaciji procesa uvođenja novog modela rada u centru za socijalnu skrb. Ljetopis socijalnog rada, 17 (3), 319-352.

6. Ajduković, M. (1996a). Sindrom sagorijevanja na poslu. U: Ajduković, D. \& Ajduković, M. (ur.), Pomoć i samopomoć u skrbi za mentalno zdravlje pomagača. Zagreb: Društvo za psihološku pomoć, 21-27. 
7. Ajduković, M. (1996b). Profesionalna pomoć pomagačima. U: Ajduković, D. \& Ajduković, M. (ur.), Pomoć i samopomoć u skrbi za mentalno zdravlje pomagača. Zagreb: Društvo za psihološku pomoć, 77-99.

8. Anderson, D. G. (2000). Coping strategies and burnout among veteran child protection workers. Child Abuse and Neglect, 839-848.

9. Arambašić, L. (2003). Stres i suočavanje - teorijski modeli i njihove implikacije za problem nezaposlenosti. Suvremena psihologija, 6 (11), 103-127.

10. Arches, J. (1991). Social structure, burnout, and job satisfaction. Social Work, 36, 193-272.

11. Barrick, R. K. (1989). Burnout and job satisfaction of vocational supervisors. Journal of Agricultural Education, 30 (4), 35-41.

12. Bednar, S. (2003). Elements of satisfying organisational climates in child welfare agencies. Families in Society, 84 (1), 7-12.

13. Bennett, P. \& Evans, R. (1993). Stress and coping in social workers: A preliminary invesstigation. British Association of Social Workers, 23, 31-44.

14. Brown, A. \& Bourne, I. (1996). The social work supervisor: Supervision in community, day care, and residential settings. Buckingham, England; Philadelphia, PA: Open University Press.

15. Cherniss, C. (1980). Professional burnout in the human service organizations. New York: Praeger.

16. Coffey, M., Dugdill, I. \& Tattersall, A. (2004). Stress in social services: Mental well-being, constraints and job satisfaction. British Journal of Social Work, 34 (5), 735-747.

17. Coffey, M., Dugdill, L. \& Tattersall, A. (2009). Working in the public sector: A case study of social services. Journal of Social Work, 9 (4), 420-442.

18. Collins, S. (2008). Statutory social workers: Job satisfaction, coping, social support and individual differences. British Journal of Social Work, 38 (6), 1173-1193.

19. Collins, S. (2013). Alternative psychological approaches for social workers and social work students dealing with stress in the UK: Sense of coherence, challenge appraisals, self-efficacy and sense of control. British Journal of Social Work, Preuzeto s: http://bjsw.oxfordjournals.org/content/early/2013/06/03/ bjsw.bct103 (15.12.2013.).

20. Cooper, C. L. \& Marshall, J. (1976). Occupational sources of stress: A review of the literature relating to coronary heart disease and mental ill health. Journal of Ocupational Psychology, 49, 11-28.

21. Cooper, C. L., Dewe, P. J. \& O’Driscoll, M. P. (2001). Organizational stress: A rewiev and critique of theory. Research and applications. Thousand Oaks CA: Sage Publications. 
O. Družić Ljubotina, Lj. Friščić: Profesionalni stres kod socijalnih radnika...

22. Cooper, C. L., Sloan, S. J. \& Williams, S. (1988). Occupational stress indicator. Management gudie. Windsor: NFER-Nelson.

23. Curtis, L., Moriarty, J. \& Netten, A. (2010). The expected working life of a social worker. British Journal of Social Work, 40 (5), 1628-1643.

24. Družić Ljubotina, O. (2013). Siromaštvo kao izazov za socijalni rad u kontekstu ekonomske krize u Hrvatskoj. Ljetopis socijalnog rada, 20 (1), 187-204

25. Edelwich, J. \& Brodsky, A. (1980). Burnout: Stages of disillusionment in the helping profession. New York: Human Sciences Press.

26. Evans, S., Huxley, P., Gately, C., Webber, M., Mears, A., Pajak, S., Medina, J., Kendall, T. \& Katona, C. (2006). Mental health, burnout and job satisfaction among mental health social workers in England and Wales. British Journal of Psychiatry, 188,75-80.

27. Farber, B. A. (1983). Stress and burnout in the human service profession. New York: Pergamon Press.

28. Felton, J. S. (1998). Burnout as a clinical entity-its importance in health care workers. Irvine: Department of Medicine, Universy of California.

29. Freudenberger, H. J. \& Richelson, G. (1980). Burn-out: How to beat the high cost of success. New York: Bantam Books.

30. Freudenberger, H. J. (1974). Staff burnout. Journal of Social Issues, 30, 159165.

31. Friščić, Lj. (2006). Čimbenici profesionalnog stresa u radu socijalnih radnika u Centru za socijalnu skrb Zagreb. Ljetopis Studijskog centra socijalnog rada, 13 (2), 347-370.

32. Goliszek, A. (1993). Stress management. London: Bantam Books.

33. IASSW (2014). http://www.iassw-aiets.org/international-definition-of-socialwork (01.02.2014.).

34. Jeleč Kaker, D. (2009). Zadovoljstvo poslom i sagorijevanje na poslu kod socijalnih radnika u zdravstvu u Republici Sloveniji. Ljetopis socijalnog rada, 16 (3), 537-549.

35. Johnson, M. \& Stone, G. L. (1987). Social workers and burnout: A psycho-logical description. Journal of Social Service Research, 10, 67-80.

36. Johnson, S., Cooper, C., Cartwright, S., Donald, I., Taylor, P. \& Millet, C. (2005). The experience of work-related stress across ocupations. Journal of Managerial Psychology, 20, (2), 178-187.

37. Jones, C. (2001). Voices from the front line: State social workers and New Labour. British Journal of Social Work, 31 (4), 547-63.

38. Jones, C. \& Novak, T. (1993). Social work today. British Journal of Social Work, $23(3), 195-212$.

39. Kahn, W. A. (1993). Caring for the caregivers: Patterns of organizational caregiving. Administrative Science Quarterly, 38, (4), 539-564. 
40. Kovačić, Z. (2003). Uvođenje supervizije u sustav socijalne skrbi Republike Hrvatske. Socijalni radnik, 6, 6-8.

41. Lait, J. \&Wallace, J. E. (2002). Stress at work. A study of organizational-professional conflict and unmet expectations. Industrial Relations, 57 (3), 463-490.

42. Lazarus, R. S. \& Folkman, S. (1984). Stress, appraisal and coping, New York: Springer Publishing Comp.

43. Lee, R. T. \& Ashforth, B. E. (1990). On the meaning of Maslach's three dimensions of burnout. Journal of Applied Psychology, 75 (6), 743-747.

44. Leiter, M. P. \& C. Maslach, C. (2011). Spriječite sagorijevanje na poslu. Zagreb: Mate d.o.o.

45. Lloyd, C., King, R., \& Chenoweth, L. (2002). Social work, stress, and burnout: A review. Journal of Mental Health, 11,255-265.

46. Ljubotina, D. \& Družić, O. (1996). Sindrom izgaranja na poslu kod pomagača i čimbenici koji utječu na stupanj izgaranja. Ljetopis Studijskog centra socijalnog rada, (3), 41-64.

47. Manzano-García, G. \& Ayala-Calvo, J. C. (2013). New Perspectives: Towards an integration of the concept »burnout" and its explanatory models. Anales de psicología, 29 (3), 800-809.

48. Maslach, C. \& Jackson, S. E. (1981). The measurement of experienced burnout. Journal of Occupational Behavior, 2, 99-113.

49. Maslach, C. \& Jackson, S. E. (1986). The Maslach Burnout Inventory. Manual (2nd ed.). CA: Consulting Psychologists Press.

50. Maslach, C. (1976). Burned out. Human Behavior, 5, 16-22.

51. Maslach, C., Jackson, S. J. \& Leiter, M. P. (1996). Maslach Burnout Inventory manual. California: Mountain View.

52. McAuliffe, D. (2005). I'm still standing: Impacts and consequences of ethical dilemmas for social workers in direct practice. Journal of Social Work Values and Ethics, 2 (1), 1-10.

53. Meyerson, D. E. (1994). Interpretations of stress in institutions: The cultural production of ambiguity and burnout. Administrative Science Quarterly, 39 (4), 628-653.

54. Michie, S. \& Williams, S. (2003). Reducing work related psychological ill health and sickness absence: A systematic literature review. Occupational and Environmental Medicine, 60 (1), 3-10.

55. Mills, L. B. \& Huebner, E. S. (1998). A prospective study of personality characteristics, occupational stressors, and burnout among school psychology practitioners. Journal of School Psychology, 36, 103-120.

56. Ministarstvo zdravstva i socijalne skrbi (2010). Novi model organizacije rada Centra za socijalnu skrb po principu Ured sve na jednom mjestu. Zagreb: Ministarstvo zdravstva i socijalne skrbi. 
O. Družić Ljubotina, Lj. Friščić: Profesionalni stres kod socijalnih radnika...

57. Moštak Skupnjak, V. (2012). Potrebe i interesi socijalnih radnika u socijalnoj skrbi za programima prevencije profesionalnog stresa. Magistarski rad. Zagreb: Pravni fakultet, Studijski centar socijalnog rada.

58. Musa, S. A. (2009). Mental health problems and job satisfaction amongst social workers in the United Emirates. International Journal of Academic Research, 1 (2), 216-220.

59. NASW (2010). http://workforce.socialworkers.org/whatsnew/stress.pdf (15.06.2012.).

60. O'Driscoll, M. P. \& Cooper, C. L. (2002). Job-related stress and burnout. In:Warr, P. (ed.), Psychology at work. Harlow: Penguin Books Ltd., 203-229.

61. Panić, G. (2011). Profesionalni stres u policiji, profesionalnom vatrogastvu i socijalnom radu. Magistarski rad. Zagreb: Pravni fakultet, Studijski centar socijalnog rada.

62. Perlman, B. \& Hartman, E. (1982). Burnout: Summary and future research. Human Relations, 35, 283-305.

63. Poulin, J. \& Walter, C. (1993). Social work burnout: A longitudial study. Social Work Research, 29 (4), 5-11.

64. Puljiz, V. (1997). Studij socijalnog rada u Hrvatskoj: Dosadašnji razvitak i aktualni problemi. Ljetopis Studijskog centra socijalnog rada, 3, 143-151.

65. Sauter, S. \& Murphy, L. (1998). Stress... at work. DHHS (NIOSH). Publication, 99-101 Cincinnati: NIOSH. Preuzeto s: http://www.cdc.gov/niosh/docs/99101/pdfs/99-101.pdf (10.09.2012.).

66. Siebert, D. C. (2005). Personal and occupational factors in burnout among practicing social workers. Society for Social Work and Research. Preuzeto s: http:// sswr.confex.com/sswr/2005/techprogram/P382.HTM (14.10.2012.).

67. Sturgess, J. \& Poulsen, A. (1983). The prevalence of burn-out in occupational therapists. Occupational Therapy in Mental Health, 3, 47-60.

68. Škrinjar J. (1996). Odnos zanimanja i strategija savladavanja burnout sindroma. Hrvatska revija za rehabilitacijska istraživanja, 32 (1), 25-36.

69. Šverko, B. (1984). Važnost rada u životu pojedinca i prilog evaluaciji jednog kognitivnog modela. Psihologija, 17 (3), 48-60.

70. Thompson, N., Stradling, S., Murphy, M. \& O'Neill, P. (1996). Stress and organizational culture. British Journal of Social Work, 26, 647-665.

71. Travers, C. J. \& Cooper, C. L. (1993). Mental health, job satisfaction and occupational stress among UK teachers. Work and Stress, 7 (3), 203-219.

72. Waters, J. A. \& Ussery, W. (2007). Police stress: History, contributing factors, symptoms and interventions. Policing: An International Journal of Police Strategies \& Management, 30 (2), 169-188.

73. Wills, T. A. (1986). Stress and coping in early adolescence: Relationships to su- 
Ljetopis socijalnog rada 2014., 21 (1), 5-32 str.

bstance use in urban school samples. Health Psychology, 5 (6), 503-529.

74. Zakon o socijalnoj skrbi (2011). Narodne novine 57/2011.

75. Zakon o socijalnoj skrbi (2012). Narodne novine 33/2012.

76. Zakon o socijalnoj skrbi (2014). Narodne novine 157/2013.

77. Zapf, D. (2002). Emotion work and psychological well-being: A review of the literature and some conceptual considerations. Human Resource Management Review, 1-32.

\section{MREŽNI IZVORI}

1. https://osha.europa.eu/en/publications/factsheets/22 (14.01.2013.). 
O. Družić Ljubotina, Lj. Friščić: Profesionalni stres kod socijalnih radnika...

Olja Družić Ljubotina

Department for Social Work

Faculty of Law

University of Zagreb

Ljiljana Friščić

Ministry of Social Policy and Youth of Republic of Croatia

\section{THE OCCUPATIONAL STRESS IN SOCIAL WORKERS: SOURCES OF STRESS AND BURNOUT}

\section{SUMMARY}

Social work professionals, like many other experts from helping professions, are exposed to the occupational stress phenomenon. The occupation stress arises from the inconsistency between work and the social environment demands and one's inability to meet these demands. Hence, its negative end result is the burnout at work. From a broader perspective it could be argued that, burn-out at work is a process that leads one to a complete professional exhaustion which could result in one feeling utterly lethargic. Thus, insight into the research on the main sources of stress and burnout at work among the social work professionals is the aim of this paper. More so, the special emphasis will be put on the local research. Finally, the paper will aim to consolidate the most frequent research findings in regards to the sources of stress and burnout at work among the social work professionals.

Key words: occupational stress, sources of stress, burnout at work, social work profession. 
